Conflict of Interest: The authors of this paper have no conflicts of interest, including specific financial interests, relationships, and/or affiliations relevant to the subject matter or materials included.

\section{References}

1. Pileri SA, Ascani S, Cox MC, Campidelli C, Bacci F, Piccioli M, Piccaluga PP, Agostinelli C, Asioli S, Novero D, Bisceglia M, Ponzoni M, Gentile A, Rinaldi P, Franco V, Vincelli D, Pileri A Jr, Gasbarra R, Falini B, Zinzani PL, Baccarani M. Myeloid sarcoma: clinico-pathologic, phenotypic and cytogenetic analysis of 92 adult patients. Leukemia 2007;21:340-350.

2. Neiman RS, Barcos M, Berard C, Bonner H, Mann R, Rydell RE, Bennett JM. Granulocytic sarcoma: a clinicopathologic study of 61 biopsied cases. Cancer 1981;48:1426-1437.
3. Nandedkar S, Kawatra M, Malukani K. Myeloid sarcoma de novo presenting as generalized lymphadenopathy. Clin Cancer Investig J 2013;2:86.

4. Yilmaz AF, Saydam G, Sahin F, Baran Y. Granulocytic sarcoma: a systematic review. Am J Blood Res 2013;3:265-270.

5. Chevallier P, Labopin M, Cornelissen J, Socié G, Rocha V, Mohty M; ALWP of EBMT. Allogeneic hematopoietic stem cell transplantation for isolated and leukemic myeloid sarcoma in adults: a report from the Acute Leukemia Working Party of the European Group for Blood and Marrow Transplantation. Haematologica 2011;96:1391-1394.

6. Antic D, Elezovic I, Milic N, Suvajdzic N, Vidovic A, Perunicic M, Djunic I, Mitrovic M, Tomin D. Is there a "gold" standard treatment for patients with isolated myeloid sarcoma? Biomed Pharmacother 2013;67:72-77.

7. Lee EYP, Anthony MP, Leung AYH, Loong F, Khong PL. Utility of FDG PET/CT in the assessment of myeloid sarcoma. AJR Am J Roentgenol 2012;198:11751179.

\title{
A Case of Leukemia Cutis with Acute Myeloid Leukemia on Azacitidine Therapy
}

\author{
Akut Miyeloid Lösemide Azasitidin Tedavisi Altında Lösemi Kutis Olgusu
}

\author{
Asude Kara ${ }^{1}$, Aslı Akın Belli ${ }^{1}$, Volkan Karakuş², Yelda Dere ${ }^{3}$, Erdal Kurtoğlu \\ ${ }^{1}$ Department of Dermatology, Muğla Sıtkı Koçman University Training and Research Hospital, Muğla, Turkey \\ ${ }^{2}$ Department of Hematology, Muğla Sıtkı Koçman University Training and Research Hospital, Muğla, Turkey \\ ${ }^{3}$ Department of Pathology, Muğla Sıtkı Koçman University Faculty of Medicine, Mugla, Turkey \\ ${ }^{4}$ Department of Hematology, Antalya Training and Research Hospital, Antalya, Turkey
}

\section{To the Editor,}

Leukemia cutis (LC) is an extramedullary form of leukemia. The frequency and onset age of $\mathrm{LC}$ depends on the subtype of underlying leukemia. Clinical presentations of $\mathrm{LC}$ can be variable but it generally appears as nodules and plaques [1]. Herein, we report a case of LC with acute myeloid leukemia on azacitidine therapy.

A 70-year-old male presented with spontaneous ecchymoses and weakness in the Hematology Outpatient Clinic. Physical examination was normal. Laboratory tests were as follows: hemoglobin: $4.1 \mathrm{~g} / \mathrm{dL}$, leukocyte count: $17.600 / \mathrm{mm}^{3}$, platelet count: $57.000 / \mathrm{mm}^{3}$, and lactate dehydrogenase: $605 \mathrm{U} / \mathrm{L}$. Peripheral blood smear revealed $60 \%$ myeloblasts. Eighty percent of blastic infiltration and positive staining with myeloperoxidase (MP0) were detected in the bone marrow biopsy. The patient was diagnosed with acute myelomonocytic leukemia (AML-M4) with the morphological and immunopathological findings. Flow cytometry of the bone marrow or peripheral blood was not done. In the conventional cytogenetic analysis done before the treatment, 20 metaphases were detected. Six of them had "add" (46,XY,add(8)(q24)[6]) and 10 were diploids and 4 were hypodiploids. In the fluorescence in situ hybridization (FISH) analysis [5q31, t(15;17)(q22-24;q21), trisomy $8, \mathrm{t}(9 ; 22)$ (q34; $q 11.2), \operatorname{inv}(16)(p 13 q 22)$, del7q31, del/inv11q23, monosomy $7, t(8 ; 21)(q 21.3 ; q 22)$, and del20q], there was no abnormality.

After four cycles of therapy with azacitidine $\left(75 \mathrm{mg} / \mathrm{m}^{2}\right.$ daily for 7 days in a month), the need for red blood cells decreased but the need for platelets remained. Furthermore, some skin lesions appeared on the trunk. On dermatological examination, multiple discrete, violaceous-erythematous papules and nodules were observed on the trunk (Figures 1a and 1b). Histopathological examination of the skin lesions showed blastic cell infiltration with large pleomorphic nuclei and narrow cytoplasm in the dermis and also positive staining with CD34, CD117, and MPO (Figures 1c and 1d). The patient was diagnosed with LC with AML-M4 relapsed in the bone marrow synchronously and the 


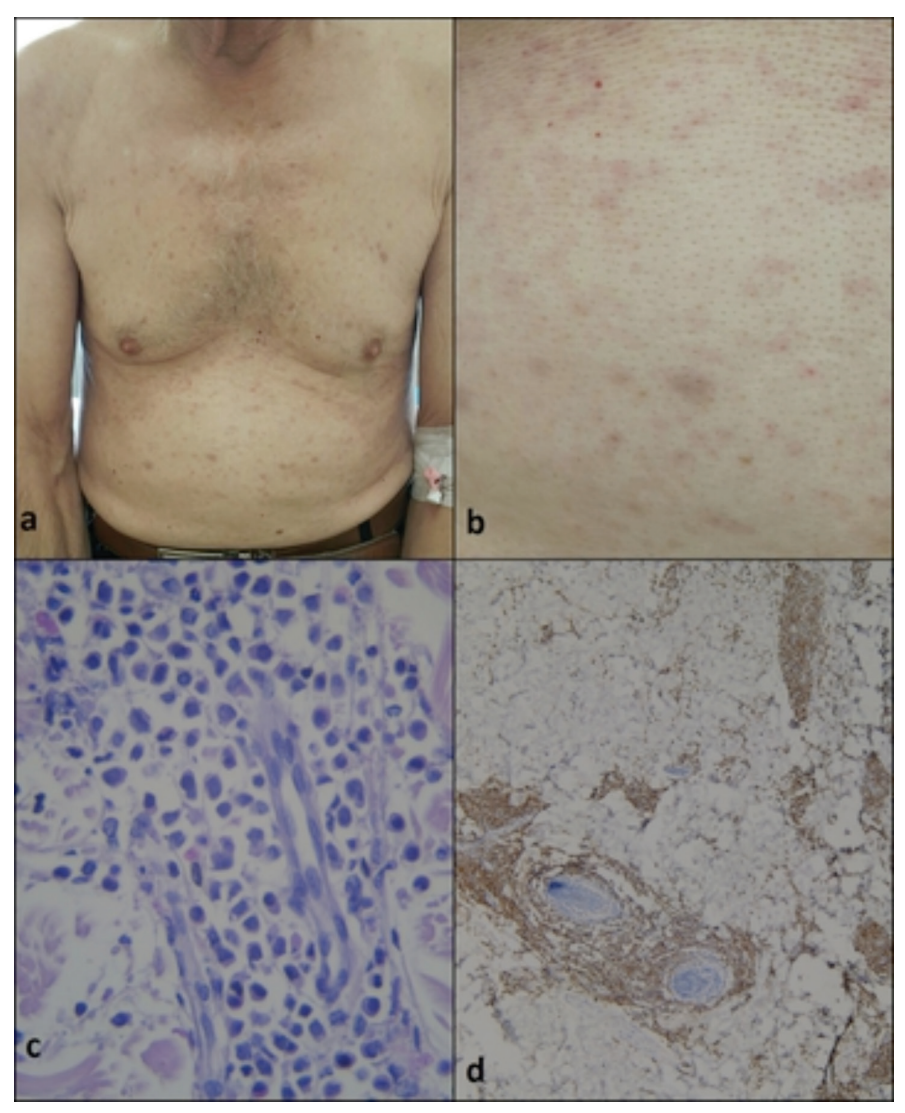

Figure 1. a) Multiple discrete, erythematous papules and nodules on the trunk. b) Closer view of the erythematous papules on the abdomen. c) Blastic cells with pleomorphic nuclei and narrow cytoplasm in the dermis (hematoxylin \& eosin, original magnification $400^{x}$ ). d) Positive staining of the blasts with myeloperoxidase (original magnification 40).

therapy regimen was changed from azacitidine to cytosinearabinoside. The same FISH panel was obtained.

LC is a rare disease characterized by leukemic cell infiltration in the dermis, subcutaneous tissue, and blood vessels. The frequency of $\mathrm{LC}$ is about $2 \%-3 \%$ in patients with AML [2]. LC mimics various dermatoses. Histopathological analysis of the lesions has an important role in the diagnosis [3]. There is no special treatment for LC and the treatment of the underlying leukemia generally improves skin lesions. Unfortunately, skin involvement of leukemia indicates poor prognosis [3].

Azacitidine is an approved and well-tolerated drug in the treatment of elderly AML patients in particular [4]. Recently, we noticed that LC cases have been reported in patients with chronic myeloid leukemia and myelodysplastic syndrome on azacitidine therapy [5]. Similarly, azacitidine therapy at the current dosage may have been insufficient in our patient and thus the cutaneous involvement developed. We want to emphasize that patients developing LC on azacitidine therapy should be accepted as refractory to the therapy and salvage therapy should be planned.

Keywords: Acute myeloid leukemia, Azacitidine, Leukemia cutis

Anahtar Sözcükler: Akut miyeloid lösemi, Azasitidin, Lösemi kutis

Conflict of Interest: The authors of this paper have no conflicts of interest, including specific financial interests, relationships, and/or affiliations relevant to the subject matter or materials included.

\section{References}

1. Wagner G, Fenchel K, Back W, Schulz A, Sachse MM. Leukemia cutis epidemiology, clinical presentation, and differential diagnoses. J Dtsch Dermatol Ges 2012;10:27-36.

2. Seok DK, Kee SY, Ko SY, Lee JH, Kim HY, Kim IS, Seo HY. Leukemia cutis in a patient with acute monocytic leukemia diagnosed simultaneously with hepatocellular carcinoma: a case study. Oncol Lett 2013;6:1319-1322.

3. Whittaker SJ. Cutaneous lymphomas and lymphocytic infiltrates. In: Burns T, Breathnach S, Cox N, Griffiths C, (eds). Rook's Text Book of Dermatology. Oxford, Wiley-Blackwell, 2010.

4. Sadashiv SK, Hilton C, Khan C, Rossetti JM, Benjamin HL, Fazal S, Sahovic E, Shadduck RK, Lister J. Efficacy and tolerability of treatment with azacitidine for 5 days in elderly patients with acute myeloid leukemia. Cancer Med 2014;3:1570-1578.

5. Infante MS, Muñoz C, Heras C, Foncillas MA, González I, Lucea I, Echavarria $\mathrm{E}$, Aramendi T, Hernández JA. Leukemia cutis in myelodysplastic syndrome and chronic myelomonocytic leukemia patients treated with adjusted dose 5-azacitidine. Eur J Dermatol 2015;25:622-623. 